\title{
'Home' Base and Monetary Base Rules: Elementary Evidence from the 1980s and 1990s
}

\author{
Philip N. Jefferson* \\ Board of Governors of the Federal Reserve System \\ Washington, DC 20551 \\ e-mail: pnj@frb.gov
}

April 1997

\begin{abstract}
This paper evaluates the quantitative importance of removing U.S. currency held abroad from the monetary base. We find that a simple macroeconometric model that uses home base has more explanatory power for changes in nominal income than when the total base is used. Moreover, proposed base rules for the conduct of monetary policy perform better when the model for home base is employed. The evidence from our elementary exercises suggests that accounting for foreign holdings of U.S. currency may be important in other contexts also.
\end{abstract}

*I thank Bennett McCallum, Athanasios Orphanides, Richard Porter, and Kendrew Witt for very helpful comments. Kendrew Witt also provided excellent research assistance. The views expressed herein do not necessarily represent those of the Board of Governors or other staff members. 


\section{Introduction}

This paper evaluates the quantitative importance of removing the stock of US currency held abroad from the monetary base. Porter and Judson (1996) report that more than 50 percent of measured currency in circulation outside banks in 1995 was held abroad. The foreign stock corresponds to the net annual flows calculated by Porter and Judson from 1977 through 1995. Subtracting the accumulated net foreign flows from total currency outstanding yields the domestic currency stock. When combined with total reserves, the domestic currency stock defines a monetary aggregate we refer to as the domestic monetary base or "home base" for short.

There are several reasons why studying foreign currency flows may be important. First, these flows can distort the relationship between narrow monetary aggregates and domestic economic activity. Such distortions could have particularly grievous consequences for the conduct of monetary policy. Second, the destination of these flows reveals the source countries of US seignorage revenue. And third, potential areas of monetary instability outside of the US can be identified by tracking these flows.

Issues relating to the first of these reasons are the focus of this paper. Friedman (1960) argues that a constant growth rate rule for a narrow monetary aggregate would, in the long run, provide the greatest degree of price stability. His analysis presumes that relatively stable relationships between the base, broader monetary aggregates, and nominal income exist. These presumptions have come under considerable scrutiny as a result of the financial innovations, regulatory reforms, and now apparent foreign currency flows of the last two decades. The apparent breakdown of stable relationships between traditional monetary aggregates and output (nominal or real) has led to a deemphasis of the aggregates in the conduct of monetary policy. ${ }^{1}$ McCallum (1993) updates the case for base rules in the conduct of monetary policy by proposing a more flexible rule than Friedman for base growth. His rule would gradually adjust base growth for changes in base velocity and allow feedback from deviations of the level of nominal income from a prescribed target path. In subsequent work, McCallum (1995) examined the robustness of his rule to variations in the econometric model of the economy.

Our interest, however, is in quantitative differences that are attributable

\footnotetext{
${ }^{1}$ Interest in the use of rules in the conduct of monetary policy, however, remains high. Proposals by Taylor (1993) and Hall and Mankiw (1994), for example, have received considerable attention.
} 
to differences in base measures. Therefore, we employ a single elementary macroeconometric model. Its specification is that of McCallum (1987, 1988a). The model is used to examine (1) the implications for the path of nominal income of base rules using the home and total bases; (2) which base measure provides more consistent subsample performance; and (3) the information content of the levels relationship between the respective base measures and nominal income. Outstanding questions are Does "correcting" the monetary base for foreign holdings of US currency matter for its relationship with income? and If so, how much does it matter? Our results provide initial answers to these questions. Significant differences in quantitative results across base measures would suggest that differentiating between home and total narrow money measures may be important in other contexts also.

The remainder of the paper is organized as follows. Section 2 contrasts home base and the total base. A replication of McCallum's (1987) concrete example using home base and total base over the complete sample for which both variables exist (1977 through 1995) is conducted in section 3 . The breakdown of the macroeconometric model in the 1984 through 1995 subperiod is documented in this section also. Section 4 shows that a slight modification of the model that incorporates readily available levels information rehabilitates the model. The rehabilitation is particularly robust for measures of home base. Section 5 concludes.

\section{2 'Home' and Total Bases}

The basic data used in this study are nominal total monetary base, nominal foreign holdings of US currency, and nominal GDP. The data are quarterly spanning from 1981:Q1 through 1995:Q4. ${ }^{2}$ We employ both the St. Louis base $^{3}$ and the Board base to insure that our results are not overly sensitive to the treatment of reserve requirements. ${ }^{4}$ The nominal foreign holdings of US currency data are the quarterly figures that add up to the annual figures reported in Porter and Judson (1996).

\footnotetext{
${ }^{2}$ More precisely, much of the analysis uses the aforementioned time span. Data prior to this sample period are used for initial conditions.

${ }^{3}$ For compatibility with previous studies, we employ the old St. Louis adjusted base as opposed to the recently released revised St. Louis adjusted base.

${ }^{4}$ Meulendyke (1990) notes that "For brief time periods, the movements of the two bases often differ. However, the differences in rates of growth are generally slight for periods of a quarter or more."
} 
Measures of home base differ from measures of the total base because holdings of US currency abroad have been netted out. Figure 1 panel A shows flows of US currency abroad from 1981 through the end of 1995. The quarterly growth of net foreign holdings ranged between one and three per cent throughout the second half of the 1980s. In the 1990s, the flows are higher on average and considerably more volatile. Panel B of figure 1 shows the flows grouped by quarter and the corresponding average quarterly flow. It indicates that these flows are not driven by seasonal factors. Rather, their general increase over time is the dominant feature. Presumably, proponents of base rules have in mind a measure that is not contaminated by such flows. If these flow estimates are accurate, it is not obvious why they would be related to domestic activity since they largely represent disastrous economic situations abroad such as hyperinflation in parts of Latin America and more recently in Russia and other parts of the former Soviet Union (see Porter and Judson, pp. 884-885). Thus, home base would be preferred as it would approximate more closely the practical concept of a narrow controllable aggregate that is the focus of rules literature. Basic statistics for the growth rate of home and total bases are presented in table 1. In panel A, we see that home base growth is lower on average, has a larger standard deviation, and has a smaller first-order autocorrelation coefficient than the total base.

The relationship between these alternative base measures and nominal income is of particular interest. Figure 2 shows the velocity of the St. Louis home and total bases. ${ }^{5}$ A striking feature of the figure is the absence of trend in home base velocity. Home base velocity has a mean of 3.301 and a standard deviation of only 0.028 (see panel B of table 1). Total base velocity, on the other hand, drifts downward over the sample. This difference is particularly noticeable after 1990 when flows of US currency abroad accelerated rapidly.

\section{Reconsideration of Previous Work}

McCallum's (1987) case for base rules was based on a simple example. He estimated the following model for nominal income, $x_{t}$, growth:

$$
\Delta x_{t}=\beta_{0}+\beta_{1} \Delta x_{t-1}+\beta_{2} \Delta b_{t-1}+\zeta_{t}
$$

\footnotetext{
${ }^{5}$ The picture for the Board measures is comparable.
} 
where $b_{t}$ is the monetary base and $\zeta_{t}$ is the error term. The data are in logarithms. McCallum (1995) proposed the base rule:

$$
\Delta b_{t}=0.00739-(1 / 16)\left(x_{t-1}-b_{t-1}-x_{t-17}+b_{t-17}\right)+\lambda\left(x_{t-1}^{* a}-x_{t-1}\right) .
$$

In this rule, three factors influence quarterly base growth. The first factor is a constant that represents the quarterly growth in target real GDP. The second factor adjusts base growth for changes in velocity over the previous four years. Finally, the third factor adjusts base growth for deviations of the level of nominal GDP from target GDP (denoted $x^{* a}$ ). The target GDP path is defined as $x_{t}^{* a}=0.2 x_{t}^{*}+0.8 x_{t}^{* *}$ which is a weighted average of a levels component, $x_{t}^{*}$, and a growth rate component, $x_{t}^{* *}$. The levels component is specified as $x_{t}^{*}=x_{t-1}^{*}+0.00739$ while the growth rate component is specified as $x_{t}^{* *}=x_{t-1}+0.00739$. An important feature of the growth rate component is that it "forgets" past level errors. The positive weight on the levels component, however, ensures that level considerations are not ignored completely. McCallum (1995) then simulated how nominal income would have evolved had the rule in equation (2) been in place using residuals from the estimation of equation (1) as a measure of the shocks to the system.

Equation (1) has become a starting point for further analyses and critiques of base rules. For example, Hess et al. (1993) and Hafer et al. (1996) study aspects of implementing base rules not considered by McCallum using equation (1). ${ }^{6}$ B. Friedman $(1988,1990)$ argues that the causal relationship implied by equation (1) is ambiguous because of the weakness of the relationship between movements in the base and nominal income in recent decades and the importance of currency in that same relationship in earlier decades. ${ }^{7}$ McCallum (1988b, 1990) responds to Friedman's reservations. It is not our objective to defend the specification in equation (1). Rather, we use equation (1) in order to contrast the performance of home base and the total base in a way that has precedence in the literature. ${ }^{8}$

\footnotetext{
${ }^{6}$ Hafer et al. (1996), for example, estimate a currency growth equation in order to decompose the simulated base into its components. They did not, however, account for the large foreign flows that plague the last decade and a half of their sample. Therefore, it's not clear how their results should be interpreted.

${ }^{7}$ Quite recently, another factor may be gaining in importance. Banks have endeavored to avoid reserve requirements by sweeping idle deposits subject to reserve requirements into accounts not subject to reserve requirements. This behavior affects the reserves component of the base and thereby influences the relationship between the base and nominal income.

${ }^{8}$ An alternative interpretation of and motivation for equation (1) that may be less contentious is offered in the next section.
} 
Table 2 shows the results of estimating equation (1) from 1981 through 1995 using St. Louis and Board measures of home base and total base. Home base out performs the total base. According to the St. Louis measures, the $\bar{R}^{2}$ using home base is over 26 percent higher than when the total base is used. The $p$-value of the coefficient on lagged base growth is also smaller. Analogous results hold for the Board measures of the base. Moreover, in this case only home base growth is clearly significant at conventional significance levels.

We repeated McCallum's simulation exercise using the estimated models for home base and total base. ${ }^{9}$ Figure 3 shows the simulated paths of nominal GDP for both St. Louis base measures. The feedback parameter, $\lambda$, was set to 0.25 , the value preferred by McCallum (1988a, 1990). The home base path of nominal GDP is marginally "closer" to its target path of nominal GDP. Table 3 shows the root mean square error (RMSE) of nominal GDP deviations from their respective target paths for home base and the total base. The RMSE is slightly lower for home base where, in percentage terms, the average control error is less than one percent. Analogous results hold for the Board measures of the base. The replication exercise indicates that home base represents a modest but statistically significant improvement over the total base.

The sample period used in our replications includes a period where the conduct of monetary policy has been characterized as placing less emphasis on the monetary aggregates. For example, Rudebusch (1995) and Hamilton (1996) indicate that federal funds rate targets have been a prominent feature of Federal Reserve policy since the first quarter of 1984. Thus, the performance of the base measures in equation (1) may be somewhat surprising. To examine the subsample robustness of the simple macroeconometric model, we re-estimated equation (1) using only data from 1984:Q1 to 1995:Q4. The results of this estimation are reported in table 4 . Generally, the base measures do not perform as well in the subsample although in each case home base does better than total base. These results suggest that much of the explanatory power of base growth for nominal income changes comes from the 1981-1984 period - a time where it is widely believed that policy placed more emphasis on the monetary aggregates.

\footnotetext{
${ }^{9}$ The replications of McCallum's example use data from 1977 to 1995. This is the entire time span for which official estimates of home base can be constructed. Data from 1977 through 1980 are used for initial conditions.
} 
These findings might also appear to suggest that the simple macroeconometric model is less useful for studying the relative performance of home base and the total base in the 1980s and 1990s. In the next section, however, the absence of trend in home base velocity is used as motivation for a slight modification to McCallum's basic specification. The modification rehabilitates the simple model. More importantly, it provides a more transparent framework for consideration of the differential information content of home and total base measures.

\section{The Elementary Model Extended}

\subsection{Specification}

Let nominal income, $x_{t}$, equal the sum of velocity, $v_{t}$, and the money stock, $m_{t}$. (Recall that the data are in logarithms.) Symbolically,

$$
x_{t}=v_{t}+m_{t} .
$$

We assume that $v_{t}$ follows a stationary stochastic process.

Let the money multiplier, $\mu_{t}$, be defined implicitly by $m_{t}=\mu_{t}+b_{t}$. We assume that $b_{t}$ is under the control of the monetary authority and that $\mu_{t}$ is a stationary stochastic process. Substituting for $m_{t}$ in equation (3) from the definition of $\mu_{t}$ yields

$$
x_{t}=\alpha_{0}+b_{t}+\varepsilon_{t} .
$$

In equation (4), the error term $\varepsilon_{t}$ follows a stationary stochastic process and includes velocity and money multiplier short-run deviations from equilibrium. The parameter $\alpha_{0}$ is a constant.

Of course, it might not be expected for equilibrium to be attained quarter by quarter but, to the extent it does not, assume that nominal income will change in order to close the gap from equilibrium. This consideration suggests an error correction specification such as

$$
\Delta x_{t}=\beta_{1} \Delta x_{t-1}+\beta_{2} \Delta b_{t-1}+\beta_{3}\left(x_{t-1}-\alpha_{0}+\alpha_{1} b_{t-1}\right)+\eta_{t}
$$

where $\eta_{t}$ is the error term and $\alpha_{1}$ is a parameter. In theory, $\alpha_{1}$ should equal one when there is no trend in the velocity of the base measure. Equation (5) is a generalization of the single equation macroeconometric models employed by McCallum (1995), Hess et al. (1993), and Hafer et al. (1996). It retains 
potentially useful information about the levels relationship between nominal income and the base. The parameter $\beta_{3}$ indicates how responsive nominal income is to disequilibrium.

\subsection{Estimation and Testing}

Figure 4 plots the logarithm of nominal income against the logarithm of home base. The sample means of both variables have been removed. The $45^{\circ}$-line closely reflects the central tendency of the observations. The fit, however, is somewhat loose. Estimation of equation (4) from 1980:Q4 through 1995:Q4 using OLS are reported in table 5. Columns 1 and 3 employ measures of home base. Columns 2 and 4 employ measures of the total base. The point estimates suggest that measures of home base approximate more closely the value of $\alpha_{1}$ implied by the theory.

Table 6 reports the results of estimating equation (5) from 1981:Q1 through 1995:Q4 using nonlinear least squares for measures of home base and the total base. ${ }^{10}$ In the total base regressions, three features of the results should be noted. First, the error correction term is not significant. Second, the coefficient on the lagged base growth is significant at conventional levels. And third, the estimated value of the coefficient on the base in the levels relationship is not close to one.

In contrast, in the home base regressions; (1) the error correction term is significant, (2) the error correction term drives out the significance of the lagged base growth term, and (3) the estimated value of the coefficient on the base in the levels relationship is much closer to one. Moreover, the equations that use home base have a much higher $\bar{R}^{2}$. This result holds across estimators (see the Appendix) and regardless of where the base is compiled.

As before, the sample period includes a period in which the conduct of monetary policy has been characterized as placing less emphasis on the monetary aggregates. Therefore, the subsample robustness of the extended model is examined. We re-estimated equation (5) using only data from 1984:Q1 to 1995:Q4 and subjected it to a number of tests. The results of the initial estimation are reported in table 7 . The extended model performs well in the subsample. In the home base regressions, there is only a very slight fall in $\bar{R}^{2}$. The error correction term is significant at the 1 percent level. In

\footnotetext{
${ }^{10}$ Estimates using Engle and Granger's (1987) two-step static OLS procedure and Stock and Watson's (1993) dynamic OLS procedure are reported in the appendix.
} 
the total base regressions, the error correction term is significant also. This suggests that the readily available levels information is even more crucial in the subsample. Overall, it appears that home base outperforms total base in the subsample. Next, we attempt to discern whether the model specification is robust over the subsample.

There is some evidence that the parameters of the estimated model are stable over the subsample period. Table 8 shows Andrews and Ploberger's (1994) exp-W and mean-Chow statistics which posit that there may be a single breakpoint somewhere in the interval from 1985:Q3 and 1994:Q3. The null hypothesis of no single breakpoint is not rejected at conventional significance levels.

A vast literature emphasizes that short run movements in velocity are related to short run fluctuations in interest rates. As a final robustness check, short term interest rates were incorporated into the extended model in order to see if the error correction term remained significant once such interest rate movements were taken into account. One at a time, either the lagged level or the lagged first difference of an interest rate was included as a regressor in equation (5). Three interest rates were employed: the threemonth treasury bill rate, the federal funds rate target, and the actual effective federal funds rate. The results of these estimations are reported in tables $9 \mathrm{a}$ and 9b. The coefficient on the level of a short term interest rate (table 9a) is statistically insignificant in all of the regressions in which it appears while the other parameters of the model are little changed. In the total base equations, however, the $p$-value of the error correction coefficient increases such that the error correction coefficient is not statistically significant at all conventional significance levels. The results in table $9 \mathrm{~b}$ indicate that including the first differences of a short term interest rate does not affect the statistical significance of the error correction term. Overall, the evidence suggests that the home base error correction term is not simply proxying for interest rate movements (or "Fed policy") over the subsample period.

\subsection{Base Rule Evaluation}

We now use the extended model to evaluate base rules for the conduct the monetary policy. Our interest is in determining whether removing the foreign component of the monetary base matters for the performance of base 
rules. ${ }^{11}$ Throughout this subsection, the simulations are conducted over the 1984:Q1 through 1995:Q4 subsample in order to avoid possible conflicts due to perceived changes in regime.

The results from simulations using McCallum's rule [equation (2)] and the extended model are reported in table 10. Figure 5 shows the simulated paths of nominal GDP for both (St. Louis) base measures. ${ }^{12}$ In this subsample, the superior performance of the rule when home base is employed in the model is more apparent. In particular, the simulated GDP path using the total base measure (panel B) starts to go off course in 1990 when currency flows abroad accelerate rapidly. One interpretation of the RMSEs in table 10 could be that if such a rule had been in place, the monetary authorities would have had almost twice as much success on average at targeting nominal income if they had used home base as opposed to the total base. That is, the home base RMSEs in table 10 are approximately one-half of those for the total base.

\section{Conclusion}

This paper provides a quantitative assessment of the importance of accounting for foreign holdings of US currency in reduced form base-to-income specifications. An evaluation of base rules was chosen as the setting because of the role such proposals have played in the development of and current thinking about monetary policy rules. We find that a simple reduced-form macroeconometric model that uses home base has more explanatory power for changes in nominal income than when the total base is used. Moreover, proposed policy rules perform better when the model for the home base is employed. The evidence from these elementary exercises suggests that accounting for foreign holdings of US currency may be important in other contexts also.

\footnotetext{
${ }^{11}$ Feldstein and Stock (1994), Fair and Howrey (1996), and Estrella and Mishkin (1996) provide comprehensive analyses of a variety of optimal monetary policy rules. The narrow measures of money they employ include US currency held abroad. Published official estimates of US currency held abroad where not available when these sophisticated studies where undertaken.

${ }^{12}$ The coefficient, $\beta_{2}$, is not statistically significant in any of the estimations of equation (5). Moreover, the sign of this coefficient varies across estimators. Therefore, it is set equal to zero in the simulations.
} 


\section{A Appendix}

\section{Two-Step Estimates}

Estimates of the cointegrating vector using Engle and Granger's (1987) static OLS estimator (SOLS) are reported in table 5 in the text. Table A1 reports the results of estimating equation (5) using the SOLS residuals as a regressor. Estimates of the cointegrating vector using Stock and Watson's (1993) dynamic OLS estimator (DOLS) are reported in table A2. Table A3 reports the results of estimating equation (5) using the DOLS residuals as a regressor. Measures of home base and the total base are employed.

\section{Unit Root Tests}

The analysis in the text appeals to economic theory for the specification of the cointegrating vector. Our view is that this is an appropriate way to proceed given the sample size and the known limitations of standard tests. ${ }^{13}$ Nonetheless, we report the results of augmented Dicker-Fuller (ADF) unit root tests for residuals from the SOLS and DOLS cointegrating regressions. The lag lengths indicated resulted from the use of the lag length selection procedure suggested by Campbell and Perron (1991). The critical values are from MacKinnon (1991). MacKinnon's table 1 is used to generate the critical values for all unit root tests reported. Table A4 reports the results of tests of the null hypothesis of the existence of a unit root in the residuals from the SOLS and DOLS cointegrating equations using home base and the total base.

\section{References}

[1] Andrews, Donald W. K. and Werner Ploberger (1994): "Optimal Tests when a Nuisance Parameter is Present only under the Alternative," Econometrica, Vol. 62, No. 6, pp. 1383-1414.

[2] Blough, Steven R. (1992): "The Relationship between Power and Level for Generic Unit Root Tests in Finite Samples," Journal of Applied Econometrics, Vol. 7, No. 3, pp. 295-308.

\footnotetext{
${ }^{13}$ Blough (1992) and Cochrane (1991) discuss the limitations of standard unit root and cointegration tests.
} 
[3] Campbell, John Y. and Pierre Perron (1991): "Pitfalls and Opportunities: What Macroeconomists Should Know about Unit Roots," in O.J. Blanchard and S. Fischer eds. NBER Macroeconomics Annual, pp. 141200, MIT Press, Cambridge, MA.

[4] Cochrane, John H. (1991): "A Critique of the Application of Unit Root Tests," Journal of Economic Dynamics and Control, Vol. 15, No. 2, pp. 279-285.

[5] Engle, Robert F. and Clive W..J. Granger (1987): "Cointegration and Error Correction: Representation, Estimation, and Testing," Econometrica, Vol. 55, No. 2, pp. 251-276.

[6] Estrella, Arturo and Frederic S. Mishkin (1996): "Is There a Role for Monetary Aggregates in the Conduct of Monetary Policy?" NBER Working Paper No. 5845.

[7] Fair, Ray C. and E. Philip Howrey (1996): "Evaluating Alternative Monetary Policy Rules," Journal of Monetary Economics, Vol. 38, No. 2, pp. 173-194.

[8] Feldstein, Martin and James H. Stock (1994): "The Use of a Monetary Aggregate to Target Nominal GDP," in Money Policy, edited by N. Gregory Mankiw, pp. 7-70, University of Chicago Press, Chicago.

[9] Friedman, Benjamin M. (1990): "Is the Monetary Base Related to Income in a Robust Way?" in Monetary Policy for a Changing Financial Environment, eds. W.S. Haraf and P. Cagan, pp. 70-77, AEI Press, Washington, D.C.

[10] _-_-- (1988): "Conducting Monetary Policy by Controlling Currency Plus Noise: A Comment," in Carnegie-Rochester Conference Series on Public Policy, Vol. 29, pp. 205-212, North-Holland, Amsterdam.

[11] Friedman, Milton (1960): A Program for Monetary Stability, Fordham University Press, New York.

[12] Hafer, R.W., Joseph H. Haslag, and Scott E. Hein (1996): "Implementing Monetary Base Rules: The Currency Problem," Journal of Economics and Business, Vol. 48, No. 5, pp. 461-472. 
[13] Hamilton, James D. (1996): "The Daily Market for Federal Funds." Journal of Political Economy, Vol. 10, No. 1, pp. 26-56.

[14] Hall, Robert E. and N. Gregory Mankiw (1994): "Nominal Income Targeting," in Money Policy, edited by N. Gregory Mankiw, pp. 71-94, University of Chicago Press, Chicago.

[15] Hess, Gregory D., David H. Small, and Flint Brayton (1993): "Nominal Income Targeting with the Monetary Base as Instrument," in Operating Procedures and the Conduct of Monetary Policy: Conference Proceedings, Vol. 2, edited by M. Goodfriend and D. H. Small, Board of Governors of the Federal Reserve System, Washington, D.C.

[16] MacKinnon, James (1991): "Critical Values for Cointegration Tests," in R.F. Engle and C.W.J. Granger eds. Long-Run Economic Relationships: Readings in Cointegration, pp. 267-276, Oxford University Press, New York.

[17] McCallum, Bennett T. (1995): "Monetary Policy Rules and Financial Stability," in Financial Stability in a Changing Environment edited by K. Sawamoto, Z. Nakajima, and H. Taguchi, pp. 389-421, St. Martin's Press.

[18] -_-_ (1993): "Specification and Analysis of a Monetary Policy Rule for Japan," Bank of Japan Monetary and Economic Studies, Vol. 11, No. 2, pp. 1-45.

[19] ----- (1990): "Targets, Indicators, and Instruments of Monetary Policy," in Monetary Policy for a Changing Financial Environment, eds. W.S. Haraf and P. Cagan, pp. 44-70, AEI Press, Washington, D.C.

[20] ----- (1988a): "Robustness Properties of a Rule for Monetary Policy," in Carnegie-Rochester Conference Series on Public Policy, Vol. 29, pp. 175-203, North-Holland, Amsterdam.

[21] _-_-_ (1988b): "Reply to Comments by Benjamin Friedman" in CarnegieRochester Conference Series on Public Policy, Vol. 29, pp. 213-214, North-Holland, Amsterdam. 
[22] ___ (1987): "The Case for Rules in the Conduct of Monetary Policy: A Concrete Example," Federal Reserve Bank of Richmond, Economic Review, Vol. 73, September-October, pp. 10-18.

[23] Meulendyke, Ann-Marie (1990): "Possible Roles for the Monetary Base," in Intermediate Targets and Indicators for Monetary Policy, pp. 20-66, Federal Reserve Bank of New York, New York.

[24] Porter, Richard and Ruth Judson (1996): "The Location of US Currency: How Much is Abroad?" Federal Reserve Bulletin, Vol. 82, No. 10, pp. 883-903.

[25] Rudebusch, Glenn D. (1995): "Federal Reserve Interest Rate Targeting, Rational Expectations, and the Term Structure," Journal of Monetary Economics, Vol. 35, No. 2, pp. 245-274.

[26] Stock, James H. and Mark W. Watson (1993): "A Simple Estimator of Cointegrating Vectors in Higher Order Integrated Systems," Econometrica, Vol. 61, No. 4, pp. 783-820.

[27] Taylor, John (1993): "Discretion versus Policy Rules in Practice" in Carnegie-Rochester Conference Series on Public Policy, Vol. 39, pp. 195214, North-Holland, Amsterdam. 
Table 1: Basic Statistics 1981-1995

\begin{tabular}{|lcccc|}
\hline \multicolumn{4}{|c|}{ Panel A: Quarterly Growth Rate } \\
& St. Louis & \multicolumn{2}{c|}{ Board } \\
mean & 1.517 & 1.821 & 1.546 & 1.868 \\
std. dev. & 0.917 & 0.668 & 0.862 & 0.611 \\
autocorr. & 0.433 & 0.565 & 0.350 & 0.575 \\
\hline \multicolumn{4}{|c}{ Panel B: Home Base Velocity } \\
mean & St. Louis & Board \\
std. dev. & 3.301 & 3.463 \\
Notes: Panel A- rates are in percent. & 0.028 & 0.028 \\
Panel B- data are in logarithms. \\
\hline
\end{tabular}

Table 2: OLS Estimates of Equation 1

\begin{tabular}{|lcccc|}
\hline \multicolumn{4}{|c}{$1981: Q 1-1995: Q 4$} \\
$\beta_{0}$ & St. Louis & \multicolumn{3}{c|}{ Board } \\
& home & total & home & total \\
& 0.004 & 0.002 & 0.005 & 0.003 \\
$\beta_{1}$ & $(0.002)$ & $(0.003)$ & $(0.002)$ & $(0.004)$ \\
& {$[0.075]$} & {$[0.563]$} & {$[0.050]$} & {$[0.369]$} \\
& 0.379 & 0.432 & 0.369 & 0.423 \\
$\beta_{2}$ & $(0.098)$ & $(0.103)$ & $(0.102)$ & $(0.106)$ \\
& {$[0.000]$} & {$[0.000]$} & {$[0.001]$} & {$[0.000]$} \\
& 0.338 & 0.353 & 0.307 & 0.281 \\
$\bar{R}^{2}$ & $(0.096)$ & $(0.141)$ & $(0.104)$ & $(0.156)$ \\
s.e.e. & {$[0.001]$} & {$[0.015]$} & {$[0.005]$} & {$[0.078]$} \\
durbin-h & 0.321 & 0.255 & 0.282 & 0.216 \\
\hline Notes: std. & 0.007 & 0.007 & 0.007 & 0.007 \\
\hline \multicolumn{4}{|c}{ errors in parentheses. $p$-values in brackets. } \\
\hline
\end{tabular}


Table 3: McCallum's Rule

1981-1995

\begin{tabular}{|ccc|}
\hline & \multicolumn{2}{c}{ St. Louis } \\
RMSE & 0.009 & total \\
& & Board \\
& home & total \\
RMSE & 0.010 & 0.012 \\
\hline
\end{tabular}

Table 4: OLS Estimates of Equation 1

\begin{tabular}{|c|c|c|c|c|}
\hline & \multicolumn{4}{|c|}{$1984: Q 1-1995: Q 4$} \\
\hline & \multicolumn{2}{|c|}{ St. Louis } & \multicolumn{2}{|c|}{ Board } \\
\hline & home & total & home & total \\
\hline \multirow[t]{3}{*}{$\beta_{0}$} & 0.007 & 0.008 & 0.007 & 0.008 \\
\hline & $(0.002)$ & $(0.003)$ & $(0.002)$ & $(0.004)$ \\
\hline & {$[0.005]$} & {$[0.029]$} & {$[0.005]$} & {$[0.036]$} \\
\hline \multirow[t]{3}{*}{$\beta_{1}$} & 0.438 & 0.460 & 0.436 & 0.456 \\
\hline & $(0.129)$ & $(0.129)$ & $(0.130)$ & $(0.130)$ \\
\hline & {$[0.001]$} & {$[0.001]$} & {$[0.002]$} & {$[0.001]$} \\
\hline \multirow[t]{3}{*}{$\beta_{2}$} & 0.077 & 0.006 & 0.083 & -0.008 \\
\hline & $(0.093)$ & $(0.126)$ & $(0.096)$ & $(0.136)$ \\
\hline & {$[0.414]$} & {$[0.965]$} & {$[0.394]$} & {$[0.955]$} \\
\hline $\bar{R}^{2}$ & 0.201 & 0.189 & 0.202 & 0.189 \\
\hline s.e.e. & 0.005 & 0.005 & 0.005 & 0.005 \\
\hline durbin-h & -1.458 & -1.171 & -1.482 & -1.160 \\
\hline
\end{tabular}


Table 5: OLS Estimates of Equation 4

\begin{tabular}{|lcccc|}
\hline & \multicolumn{2}{c}{ St. Louis } & \multicolumn{2}{c|}{ Board } \\
& home & total & home & total \\
$\alpha_{0}$ & 3.549 & 3.931 & 3.764 & 4.120 \\
$\alpha_{1}$ & 0.952 & 0.813 & 0.940 & 0.794 \\
\hline
\end{tabular}

Table 6: NLLS Estimates of Equation 5

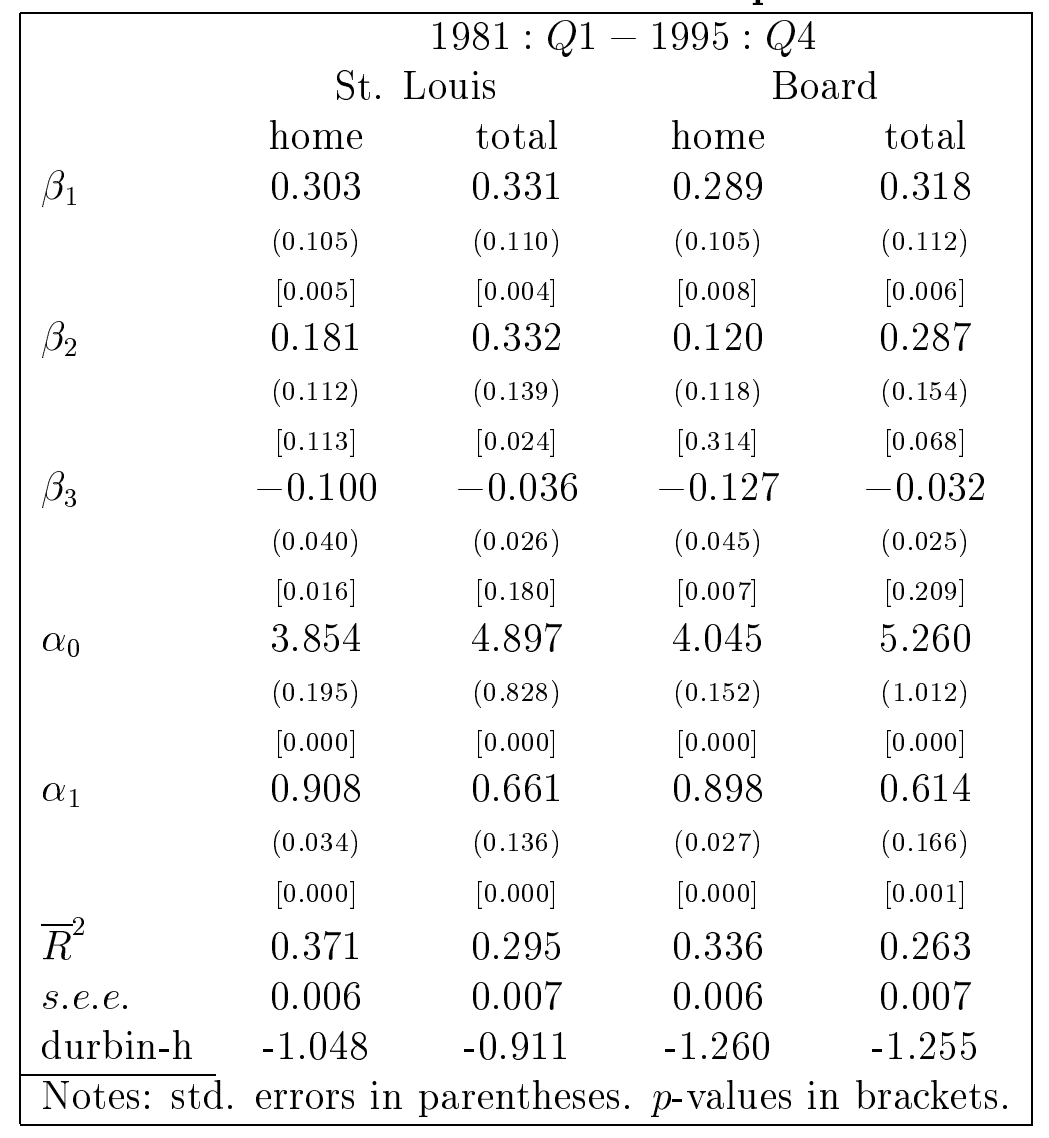


Table 7: NLLS Estimates of Equation 5

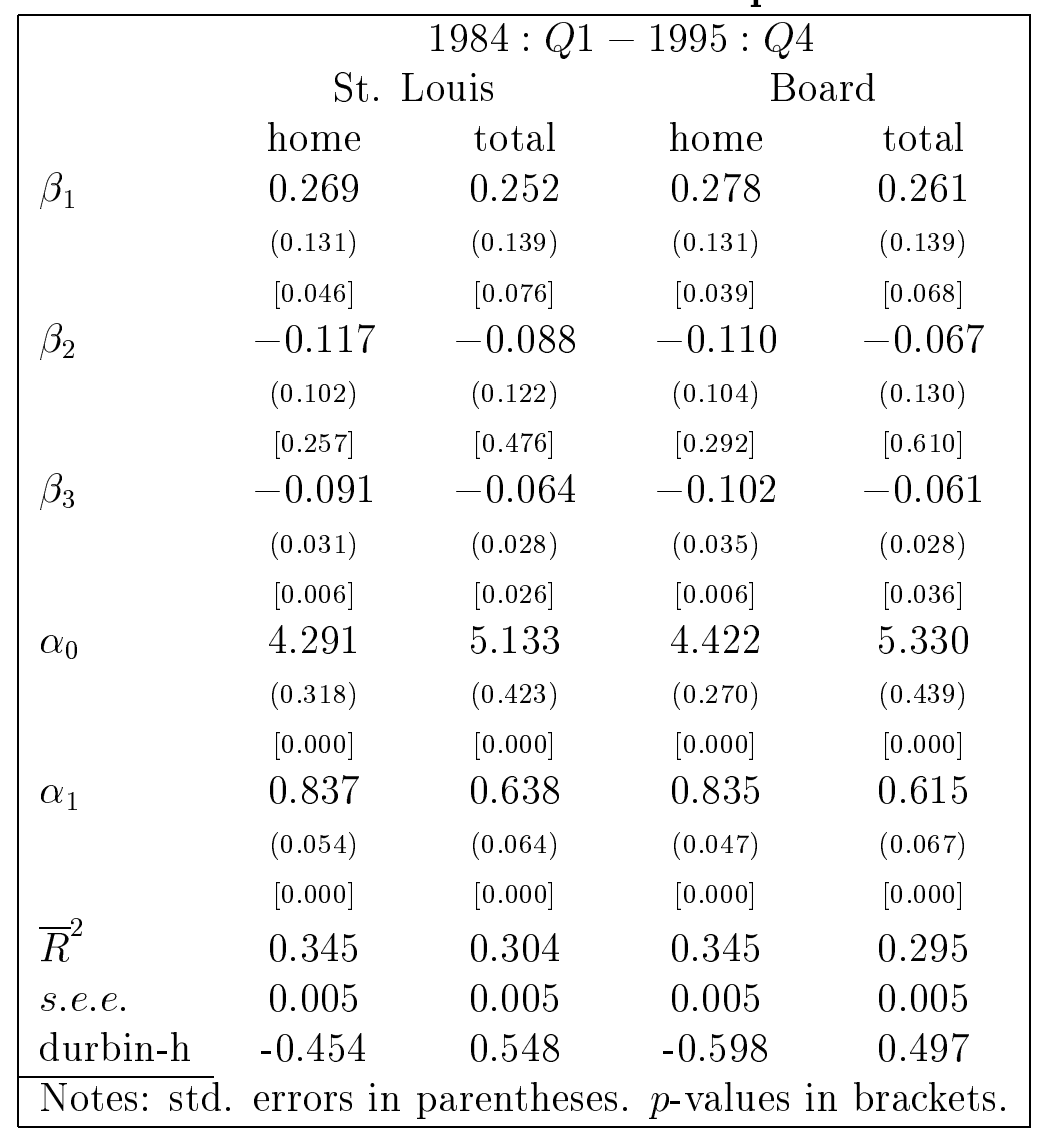

Table 8: Tests for Structural Change

\begin{tabular}{|lllll|}
\hline & \multicolumn{2}{c}{ St. Louis } & \multicolumn{2}{c|}{ Board } \\
home & total & home & total \\
mean-Chow & 1.447 & 2.099 & 1.778 & 2.411 \\
AP exp-W & 1.067 & 1.518 & 1.437 & 1.885 \\
\hline \multicolumn{2}{|l}{ Notes: Critical values are tabulated in } \\
Andrews and Ploberger (1994).
\end{tabular}


Table 9a: Interest Rate Levels in Equation 5

\begin{tabular}{|c|c|c|c|c|}
\hline & & $\begin{array}{r}1984: Q 1 \\
\text { St. }\end{array}$ & $\begin{array}{l}1995: Q 4 \\
\text { ouis }\end{array}$ & \\
\hline & & & & \\
\hline FF target & $\begin{array}{c}(-0.001 \\
(0.001)\end{array}$ & $\begin{array}{c}-0.085) \\
(0.032)\end{array}$ & $\begin{array}{c}(-0.001 \\
(0.001)\end{array}$ & $\begin{array}{c}-0.054) \\
(0.030)\end{array}$ \\
\hline & {$[0.365]$} & [0.011] & {$[0.408]$} & {$[0.078]$} \\
\hline FF rate & $(-0.001$ & $-0.085)$ & $(-0.001$ & $-0.053)$ \\
\hline & $(0.001)$ & $(0.032)$ & $(0.001)$ & $(0.030)$ \\
\hline & {$[0.278]$} & {$[0.010]$} & {$[0.346]$} & {$[0.085]$} \\
\hline T-bill & $(-0.001$ & $-0.082)$ & $(-0.001$ & $-0.055)$ \\
\hline & $(0.001)$ & $(0.033)$ & $(0.001)$ & $(0.029)$ \\
\hline & {$[0.463]$} & {$[0.018]$} & {$[0.344]$} & {$[0.069]$} \\
\hline & & & & \\
\hline & & & & \\
\hline FF target & $(-0.001$ & $-0.098)$ & $(-0.001$ & $-0.052)$ \\
\hline & $(0.001)$ & $(0.036)$ & $(0.001)$ & $(0.031)$ \\
\hline & {$[0.378]$} & {$[0.009]$} & {$[0.450]$} & {$[0.093]$} \\
\hline FF rate & $(-0.001$, & $-0.098)$ & $(-0.001$, & $-0.051)$ \\
\hline & $(0.001)$ & $(0.035)$ & $(0.001)$ & $(0.031)$ \\
\hline & [0.295] & {$[0.008]$} & [0.390] & {$[0.101]$} \\
\hline T-bill & $(-0.000$ & $-0.095)$ & $(-0.001$, & $-0.053)$ \\
\hline & $(0.001)$ & $(0.037)$ & $(0.001)$ & $(0.030)$ \\
\hline & {$[0.480]$} & {$[0.013]$} & {$[0.366]$} & {$[0.082]$} \\
\hline $\begin{array}{l}\text { Notes: Cell } \\
\text { and error cor } \\
5 \text { with the la } \\
\text { as a regresso } \\
\text { correction co }\end{array}$ & $\begin{array}{l}\text { tries report } \\
\text { ection coeffic } \\
\text { ged level of t } \\
\text { Cell entries } \\
\text { ficient). Std }\end{array}$ & $\begin{array}{l}\text { imates of th } \\
\text { th for the } \mathrm{N} \\
\text { given inter } \\
\text { e: (interest } \\
\text { rrors in par }\end{array}$ & $\begin{array}{l}\text { nterest rate } \\
\text { S estimation } \\
\text { rate include } \\
\text { e coefficient } \\
\text { heses. } p \text {-val }\end{array}$ & $\begin{array}{l}\text { fficient } \\
\text { equation } \\
\text { ror } \\
\text { in brackets }\end{array}$ \\
\hline
\end{tabular}


Table 9b: Interest Rate Differences in Equation $\mathbf{5}$

\begin{tabular}{|c|c|c|c|c|}
\hline \multirow[b]{3}{*}{ FF target } & \multicolumn{4}{|c|}{$\begin{array}{c}1984: \text { Q } 1-1995: Q 4 \\
\text { St. Louis }\end{array}$} \\
\hline & \multicolumn{2}{|c|}{ home } & \multicolumn{2}{|c|}{ total } \\
\hline & $\begin{array}{c}(-0.002, \\
(0.002)\end{array}$ & $\begin{array}{c}-0.107) \\
(0.034)\end{array}$ & $\begin{array}{c}(-0.001 \\
(0.001)\end{array}$ & $\begin{array}{c}-0.067) \\
(0.029)\end{array}$ \\
\hline & {$[0.254]$} & {$[0.003]$} & {$[0.657]$} & {$[0.024]$} \\
\hline FF rate & $\begin{array}{c}(-0.002, \\
(0.001)\end{array}$ & $\begin{array}{c}-0.109) \\
(0.033)\end{array}$ & $\begin{array}{c}(-0.001, \\
(0.001)\end{array}$ & $\begin{array}{c}-0.068) \\
(0.028)\end{array}$ \\
\hline \multirow[t]{4}{*}{ T-bill } & $\begin{array}{c}{[0.150]} \\
(-0.002 \\
(0.002)\end{array}$ & $\begin{array}{c}{[0.002]} \\
-0.108) \\
(0.034)\end{array}$ & $\begin{array}{c}{[0.442]} \\
(-0.000, \\
(0.002)\end{array}$ & $\begin{array}{c}{[0.020]} \\
-0.065) \\
(0.028)\end{array}$ \\
\hline & {$[0.233]$} & {$[0.003]$} & {$[0.774]$} & {$[0.026]$} \\
\hline & \multicolumn{4}{|c|}{ Board } \\
\hline & \multicolumn{2}{|c|}{ home } & \multicolumn{2}{|c|}{ total } \\
\hline FF target & $\begin{array}{c}(-0.002, \\
(0.002)\end{array}$ & $\begin{array}{c}-0.118) \\
(0.038)\end{array}$ & $\begin{array}{c}(-0.000 \\
(0.001)\end{array}$ & $\begin{array}{c}-0.063) \\
(0.029)\end{array}$ \\
\hline & {$[0.295]$} & {$[0.004]$} & {$[0.747]$} & {$[0.035]$} \\
\hline $\mathrm{FF}$ rate & $\begin{array}{c}(-0.002, \\
(0.001)\end{array}$ & $\begin{array}{c}-0.120) \\
(0.037)\end{array}$ & $\begin{array}{c}(-0.001 \\
(0.001)\end{array}$ & $\begin{array}{c}-0.064) \\
(0.029)\end{array}$ \\
\hline \multirow{3}{*}{ T-bill } & {$[0.178]$} & {$[0.002]$} & {$[0.511]$} & {$[0.031]$} \\
\hline & $\begin{array}{c}(-0.002, \\
(0.002)\end{array}$ & $\begin{array}{c}-0.119) \\
(0.038)\end{array}$ & $\begin{array}{c}(-0.000) \\
(0.002)\end{array}$ & $\begin{array}{c}-0.062) \\
(0.029)\end{array}$ \\
\hline & {$[0.271]$} & {$[0.003]$} & {$[0.868]$} & {$[0.037]$} \\
\hline
\end{tabular}


Table 10: McCallum's Rule 1984-1995

\begin{tabular}{|ccc|}
\hline & \multicolumn{2}{c}{ St. Louis } \\
& home & total \\
RMSE & 0.011 & 0.020 \\
\hline & & Board \\
& home & total \\
RMSE & 0.011 & 0.021 \\
\hline
\end{tabular}


Table A1: SOLS Residuals in Equation 5

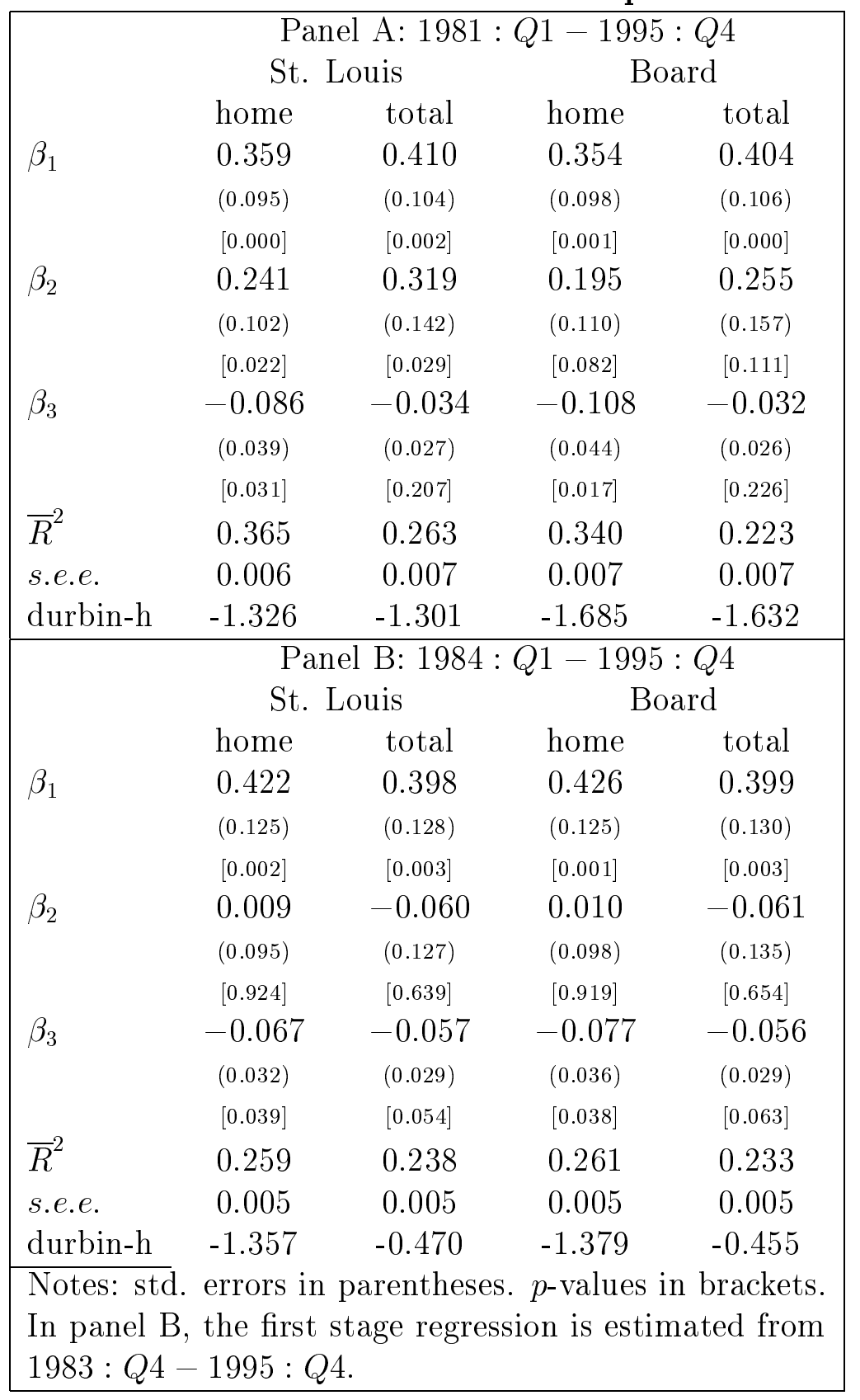


Table A2: DOLS Estimates of

Equation 4

\begin{tabular}{|c|c|c|c|c|}
\hline & & $3: Q$ & -1995 & \\
\hline & St. & ouis & & \\
\hline & home & total & home & total \\
\hline$\alpha_{0}$ & 3.707 & 3.873 & 3.910 & 4.042 \\
\hline$\alpha_{1}$ & 0.928 & 0.830 & 0.918 & 0.815 \\
\hline
\end{tabular}


Table A3: DOLS Residuals in Equation 5

\begin{tabular}{|c|c|c|c|c|}
\hline & & A: 1981 & $21-199$ & $\overline{Q 2}$ \\
\hline & St. & uis & & \\
\hline & home & total & home & total \\
\hline$\beta_{1}$ & 0.396 & 0.437 & 0.380 & 0.423 \\
\hline & $(0.095)$ & $(0.104)$ & $(0.099)$ & $(0.108)$ \\
\hline & {$[0.000]$} & {$[0.000]$} & {$[0.000]$} & {$[0.000]$} \\
\hline$\beta_{2}$ & 0.329 & 0.338 & 0.288 & 0.244 \\
\hline & $(0.094)$ & $(0.151)$ & $(0.104)$ & $(0.175)$ \\
\hline & {$[0.001]$} & {$[0.030]$} & {$[0.008]$} & {$[0.159]$} \\
\hline$\beta_{3}$ & -0.129 & -0.031 & -0.140 & -0.021 \\
\hline & $(0.047)$ & $(0.031)$ & $(0.054)$ & $(0.030)$ \\
\hline & {$[0.008]$} & {$[0.321]$} & {$[0.013]$} & {$[0.484]$} \\
\hline $\bar{R}^{2}$ & 0.384 & 0.245 & 0.340 & 0.197 \\
\hline s.e.e. & 0.006 & 0.007 & 0.007 & 0.007 \\
\hline durbin-h & -1.464 & -1.463 & -1.822 & -1.893 \\
\hline & & l B: 1984 & $21-199$ & $Q 2$ \\
\hline & St. & uis & & \\
\hline & home & total & home & total \\
\hline$\beta_{1}$ & 0.446 & 0.396 & 0.447 & 0.388 \\
\hline & $(0.124)$ & $(0.128)$ & $(0.125)$ & $(0.132)$ \\
\hline & {$[0.001]$} & {$[0.003]$} & {$[0.001]$} & {$[0.005]$} \\
\hline$\beta_{2}$ & 0.043 & -0.090 & 0.037 & -0.130 \\
\hline & $(0.091)$ & $(0.131)$ & $(0.096)$ & $(0.144)$ \\
\hline & {$[0.636]$} & {$[0.497]$} & {$[0.705]$} & {$[0.373]$} \\
\hline$\beta_{3}$ & -0.100 & -0.082 & -0.107 & -0.070 \\
\hline & $(0.041)$ & $(0.038)$ & $(0.048)$ & $(0.038)$ \\
\hline & {$[0.019]$} & {$[0.035]$} & {$[0.032]$} & {$[0.074]$} \\
\hline $\bar{R}^{2}$ & 0.287 & 0.270 & 0.272 & 0.253 \\
\hline s.e.e. & 0.005 & 0.005 & 0.005 & 0.005 \\
\hline durbin-h & -1.258 & -0.008 & -1.385 & -0.135 \\
\hline $\begin{array}{l}\text { Notes: stc } \\
\text { In panel } \\
1983: Q 4\end{array}$ & $\begin{array}{l}\text { errors } i \\
\text { the firs } \\
1995:\end{array}$ & $\begin{array}{l}\text { arenthes } \\
\text { age regr }\end{array}$ & $\begin{array}{l}p \text {-value } \\
\text { on is est }\end{array}$ & $\begin{array}{l}\text { brackets } \\
\text { ated from }\end{array}$ \\
\hline
\end{tabular}


Table A4: Cointegration Tests

\begin{tabular}{|c|c|c|}
\hline Panel A & $\begin{array}{l}1981: \\
\text { St. Louis } \\
\text { home }\end{array}$ & $\begin{array}{l}5: Q 2 \\
\text { and Nominal GDP } \\
\quad \text { total }\end{array}$ \\
\hline SOLS & $-3.492(3)$ & $-2.212(2)$ \\
\hline DOLS & $-2.314(0)$ & $-1.427(1)$ \\
\hline Panel & $\begin{array}{l}\text { B: Board n } \\
\text { home }\end{array}$ & $\begin{array}{l}\text { nd Nominal GDP } \\
\text { total }\end{array}$ \\
\hline SOLS & $-2.977(2)$ & $-2.024(2)$ \\
\hline DOLS & $-2.428(0)$ & $-1.322(0)$ \\
\hline $\begin{array}{l}\text { Notes: T } \\
\text { lengths: } \\
\text { are }-3.44\end{array}$ & $\begin{array}{l}\text { he numbers } \mathrm{i} \\
\mathrm{k}-\mathrm{max}=4 . \mathrm{Tl} \\
7 \text { and }-3.121 \text {, }\end{array}$ & $\begin{array}{l}\text { es are the optimal lag } \\
0 \% \text { critical values } \\
.\end{array}$ \\
\hline
\end{tabular}

